\title{
An Exploratory Discussion of a British Apparel Brand in Relation to New Markets: Developing Actionable Recommendations Based on Network, Relationship, and Collaboration Perspectives
}

\author{
Le Thuy Linh ${ }^{1}$, Hiroko Oe ${ }^{2}$ \\ ${ }^{1}$ MSc candidate of International Management at Bournemouth University, UK \\ ${ }^{2}$ Bournmeouth University, $U K$ \\ hoe@bournemouth.ac.uk
}

\begin{abstract}
Marks and Spencer $(M \& S)$ is a leading UK fashion retailer. However, the organisation is struggling to improve its domestic operation and to achieve its international objectives, most notably manifest through its withdrawal from China. Through conducting a critical analysis and an evaluation of the supply networks of $M \& S$, the global apparel industry and the Chinese market, this discussion paper aims to propose a new set of strategies for M\&S's re-entry. Based on an analytical discussion, the following actionable recommendations are proposed for the company: (1) to seek suitable network partners in China, (2) to build sustainable relationships with relevant partners to build business strategies based on Chinese consumers' perspectives and behaviour, and (3) to focus on a new value chain to enhance profitability and sustainability in the new market.
\end{abstract}

Keywords

MSS; Bitish apparel; entry strategies, apparel market; global network perspectives

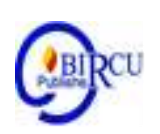

\section{Introduction}

The Current Resource-Based Analysis and Evaluation Of M\&S 1.1 M\&S's Supply Network and the Attendant Strategies

M\&S has partnered up with 880 factories across 41 countries, with China, Cambodia, and Vietnam serving as the top suppliers (M\&S ca. 2020a). However, the organisation is operating though a bulky network of 18 distribution centres (DCs) and warehouses and is suffering from insufficient stock availability (Wood 2020a). In order to tackle these longstanding problems, $M \& S$ is aiming to implement a single-tier distribution network such that its products can be delivered directly from the suppliers to the DCs and then straight to the stores. Here, numerous changes have been announced, with the closure of many DCs until 2021 (M\&S, 2018). 


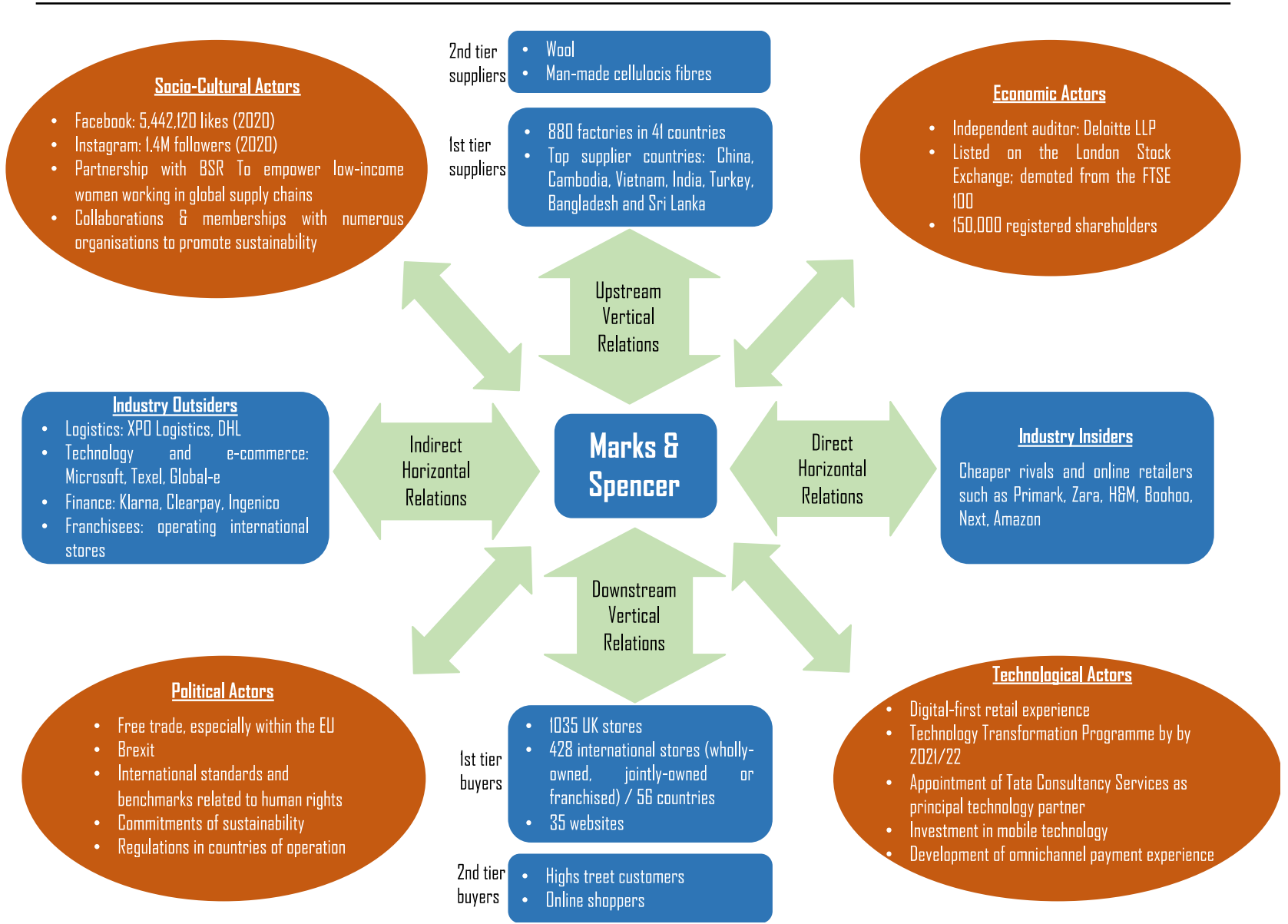

Figure 1. M\&S's business network and its relational actors (adapted from De Wit, 2017)

High-street customers are the main target of $M \& S$, while the brand is commonly regarded as a brand for middle-aged groups with limited choices and outdated styles (Hooker and Espiner, 2018; Wood and Butler, 2019). Brand equity is also an issue, with M\&S placed in the not-so-favourable mid-level price and quality bracket (Ritson 2017). While the firm operates in 57 countries and has over 1,400 stores (M\&S 2019a), with conventional highstreet retailers operating under the threat of the real estate market, online competitors and cheap rivals, an extensive offline network would no longer appear to be an appropriate arrangement (Wood and Butler, 2018a; Wood, 2019a, 2020b). In the UK, against the backdrop of plunging sales and profits, a transformation plan has been implemented, which includes shutting down 100 stores until 2022 and reducing the floor space for clothing and homeware by $25 \%$ (Wood and Butler, 2018b). The firm's international ambitions have not been fruitful either, with a number of major overseas stores closing, including in China (Wood 2016). Figure 1 presents an overview of M\&S's relational network.

Due to these closures, $M \& S$ has been forced to focus more on the e-commerce platforms. Here, in order to provide a better user experience, $M \& S$ has collaborated with various technological partners, including Microsoft in terms of artificial intelligence (AI), Texel in terms of 3D scanning technology, and Global-e in terms of e-commerce breakthrough (Santamaria, 2018; Briggs, 2019; M\&S, 2019b). The M\&S platform includes a diverse array of payment solutions, including Klarna (buy now, pay later), Clearpay (instalments), and Ingenico (omnichannel payment) (Wood, 2019b; M\&S 2019c; Ingenico, 2019). However, the low percentage of online products and the unsatisfactory website design remain the major limitations (Vincent 2018). 


\subsection{The Global Apparel Industry and Market}

Accounting for a major part of the economy of most countries, the apparel industry is a large-scale, long-service-life global industry (Cheng et al., 2018), one that encompasses a great variety of processes, from creating the products from the raw materials to delivering them to the end customers.

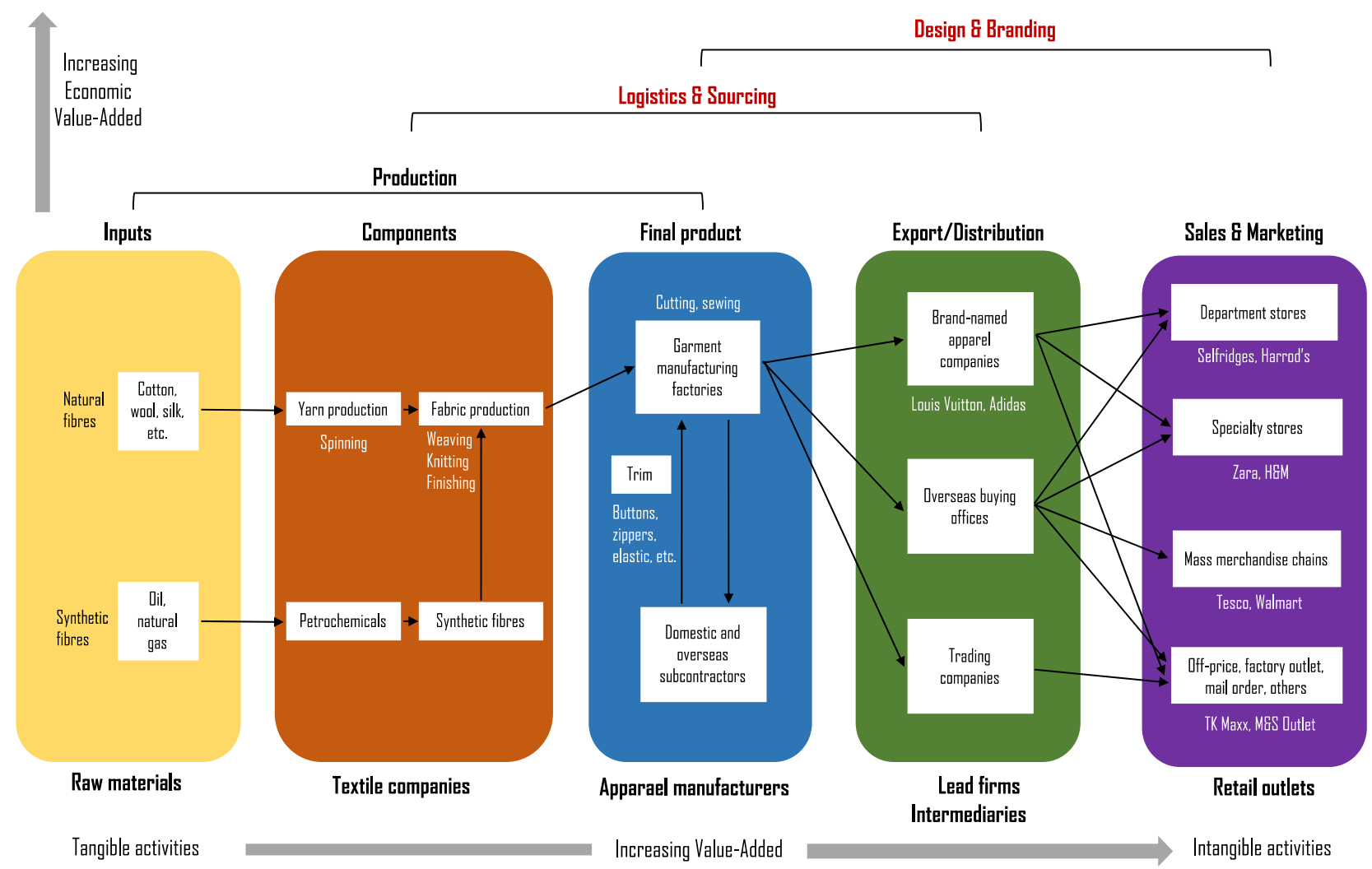

Figure 2. Global apparel value chain (adapted from Appelbaum and Gereffi, 1994)

According to Gereffi and Frederick (2010), the industry's value chain is a common example of a buyer-driven chain, in which the buyers are largely leading firms from developed countries (e.g. the US and the major European countries). This includes large retailers, brand marketers, brand manufacturers, and trading companies, who tend to take control of the most profitable activities such as research and development, designing, branding, marketing and retailing, while the manufacturing and production tend to be conducted in export-based developing countries (e.g. Southeast Asian countries). To compete in this major industry, commercial firms must align their strategies with the demands and expectations of the consumers (Macchion et al., 2015), with the post-production activities appropriately controlled to increase profitability and to upgrade the value chain.

In recent years, the fast-fashion industry has experienced a notable boom, wherein retailers such as H\&M and Zara have re-standardised the fashion concepts in terms of fast turnover and short product life cycles (Bhardwaj and Fairhurst, 2010). This industry is facilitated by a low cost, yet rapid and innovative supply chain, which includes a rapid design process, responsive suppliers and diversified sales channels (Maguire, 2019). However, this trend has been affected by the concern over issues of sustainability. The massive production process and the cheap pricing have led to the emergence of single-use purchases and, consequently, an alarming level of environmental pollution (Stein, 2019). In view of this, 
recycling and sustainable action plans are being highly endorsed by the governments, retailers, and consumers alike (Butler, 2018; Romdonny and Rosmadi, 2019).

With the proliferation of e-commerce, retailers are showing a preference for an omnichannel process that allows for providing a good customer experience across different channels without interruption or annoyance (Rizzo, 2019). The line between the offline and online platforms has become increasingly blurred as organisations continue to attempt to fulfil the various customer needs using physical or digital arrangements, or a mixture of both (Figure 3). By exploiting the omnichannel strategy, digital-first retailers (e.g. Asos, Boohoo) are enticing an increasing number of young customers and are gradually beginning to dominate the market (Maguire 2019).

\section{Fulfillment}

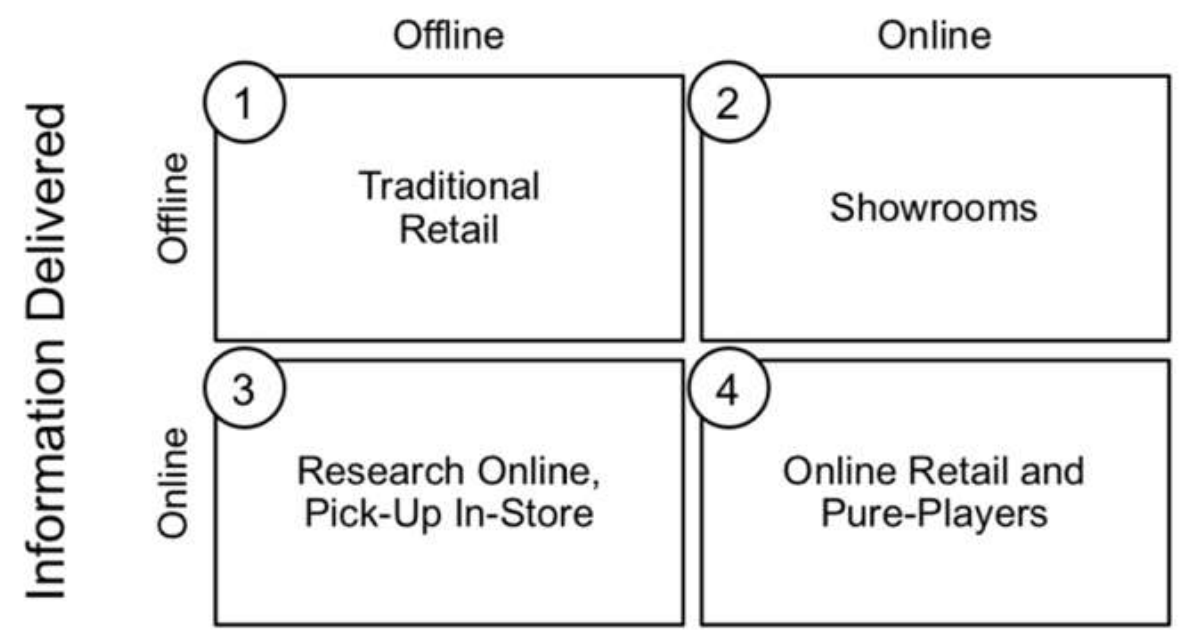

Figure 3. The information and fulfilment matrix (adapted from Bell et al., 2018)

\subsection{China's Apparel Industry and Market}

The apparel industry holds a fundamental position in China's national economy, with the nation found to be the top textile and clothing exporter by the World Trade Organisation (2019). In terms of the global apparel value chain, China is a major player in terms of manufacturing and exporting, with an abundant and cheap labour force, substantial raw materials and an all-inclusive textile industrial chain (Zhang et al., 2015). However, the country has long been criticised for its lack of research and development and its heavy reliance on foreign brands (Guan et al., 2019).

In fact, at present, China is upgrading its apparel value chain by encouraging fashion design and promoting brand establishment. The transference of the manufacturing processes to less developed countries in Asia has indicated the country's efforts to detach the labourintensive tasks from the overall network and to retain the high value-added activities and technological innovations (Liu and Yang, 2019). Hence, the national competitiveness is expected to be enhanced and sustained in the face of the penetration of foreign rivals.

The huge domestic purchasing power has created a remarkable opportunity for increased apparel sales (Fu, 2015). The mid-end sector is where the most intense competition ensues. Here, many leading Western fast-fashion brands have been falling behind in the race due to the preference for more affordable domestic merchandise ( $\mathrm{Wu}, 2019)$. Indeed, local consumption is now widely favoured, with the trend heading toward home-grown brands and personalities and the fulfilment of integrated shopping experiences (Xie, 2019). Figure 4 
presents the network of relationships among the various sectors of the Chinese textile and apparel industrial along with various attendant factors.

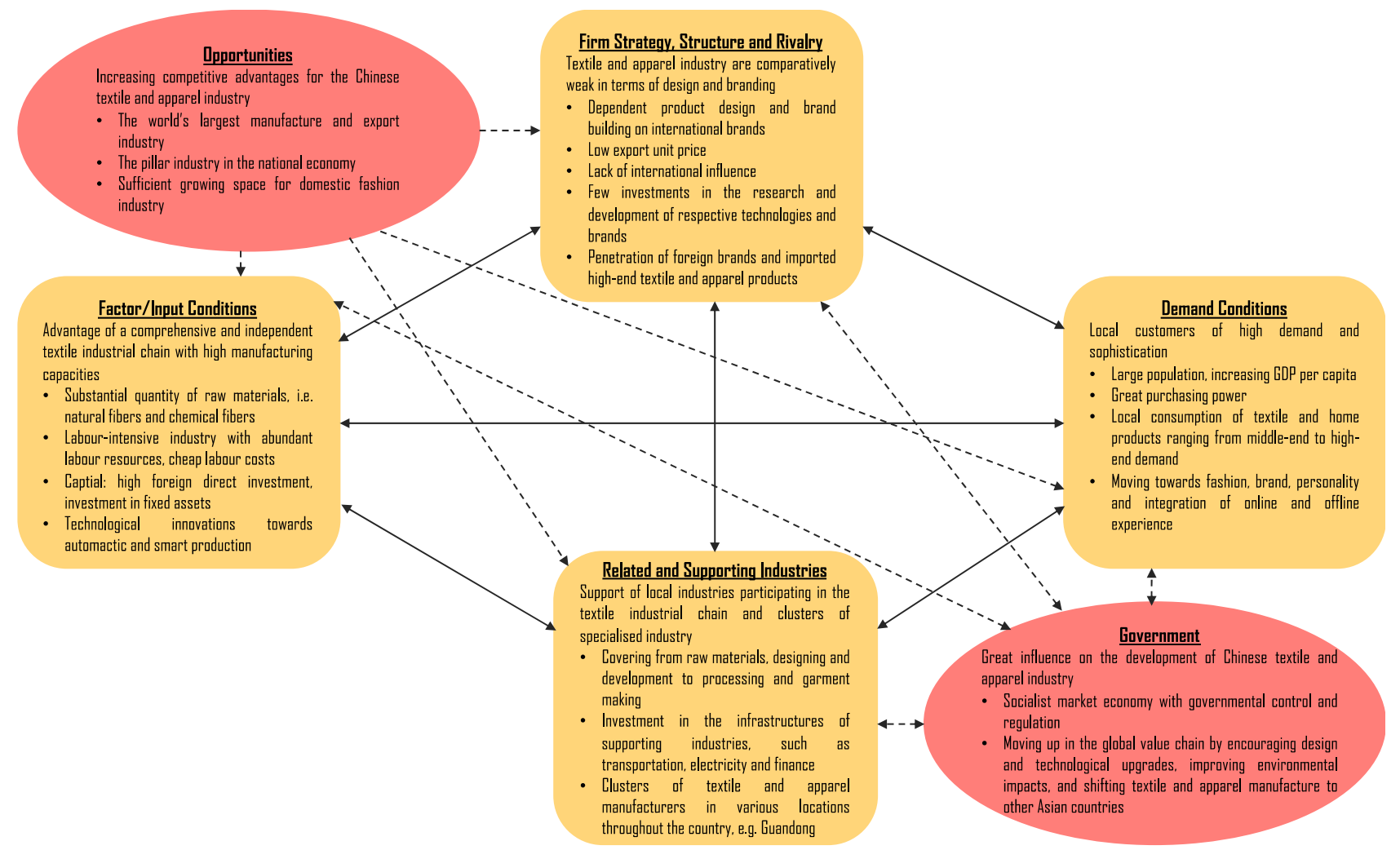

Figure 4. Factors affecting the Chinese textile and apparel industry (adapted from Porter,

1990)

China is regarded as presenting the most significant e-commerce market, especially in terms of apparel retailing ( $\mathrm{Bu}$ et al. 2019). The evolution of social media and $\mathrm{B} 2 \mathrm{C}$ ecommerce platforms has significantly furthered the power of the consumers within the value chain, wherein the transactions are largely driven by consumer demand and feedback (Li et al., 2019). Meanwhile, due to the mobile-first behaviour of Chinese shoppers, cashless payment is preferred, which has resulted in the contribution of numerous giant technology groups such as the Alibaba Group with its exclusive financial solution (Alipay) (Birtwhistle, 2017).

China's apparel industry is peeling off the export-oriented label and is enriching the highly beneficial activities within the domestic market. As such, foreign participants are being increasingly challenged by local consumption and are having to adjust to the dominance of social media and e-commerce.

\section{Review of Literatures}

\section{Proposed Strategies}

\subsection{Market Positioning}

Initially, M\&S must classify the potential and profitable customer segments. In recent times, the so-called 'millennials' have had the strongest impact on China's consumer market (Achim 2019). This group tends to include fairly high-spending customers who see fashion purchases as a means to leverage their image and social status (Zheng, 2017). A survey from Fung Business Intelligence (FBI) (2018) shows that women are the top spenders as they are 
driven by a variety of aspects, including impulse buying. As such, female millennials should be M\&S's main target audience.

Chinese consumers generally perceive Western brands in terms of high quality and good value for money (Rooney, 2019). In addition to womenswear and menswear, sport swear has reportedly enjoyed a recent rapid growth in sales, indicating the growing interest of Chinese consumers for health and fitness (FBI 2019). Meanwhile, sustainable products are receiving more attention, with sustainability becoming an increasingly strong influential factor behind purchase intentions (Zheng 2019a; Jung et al. 2020).

M\&S's failure has been largely attributed to inappropriate brand positioning and negative consumer perceptions in terms of price and value (Rapp, 2018). As a mid-end brand, a differentiation strategy must be implemented to re-establish M\&S's competitive advantage. Figure 5 presents the generic strategic dimensions of market positioning with the recommended strategy of 'differentiation' with detailed discussions.

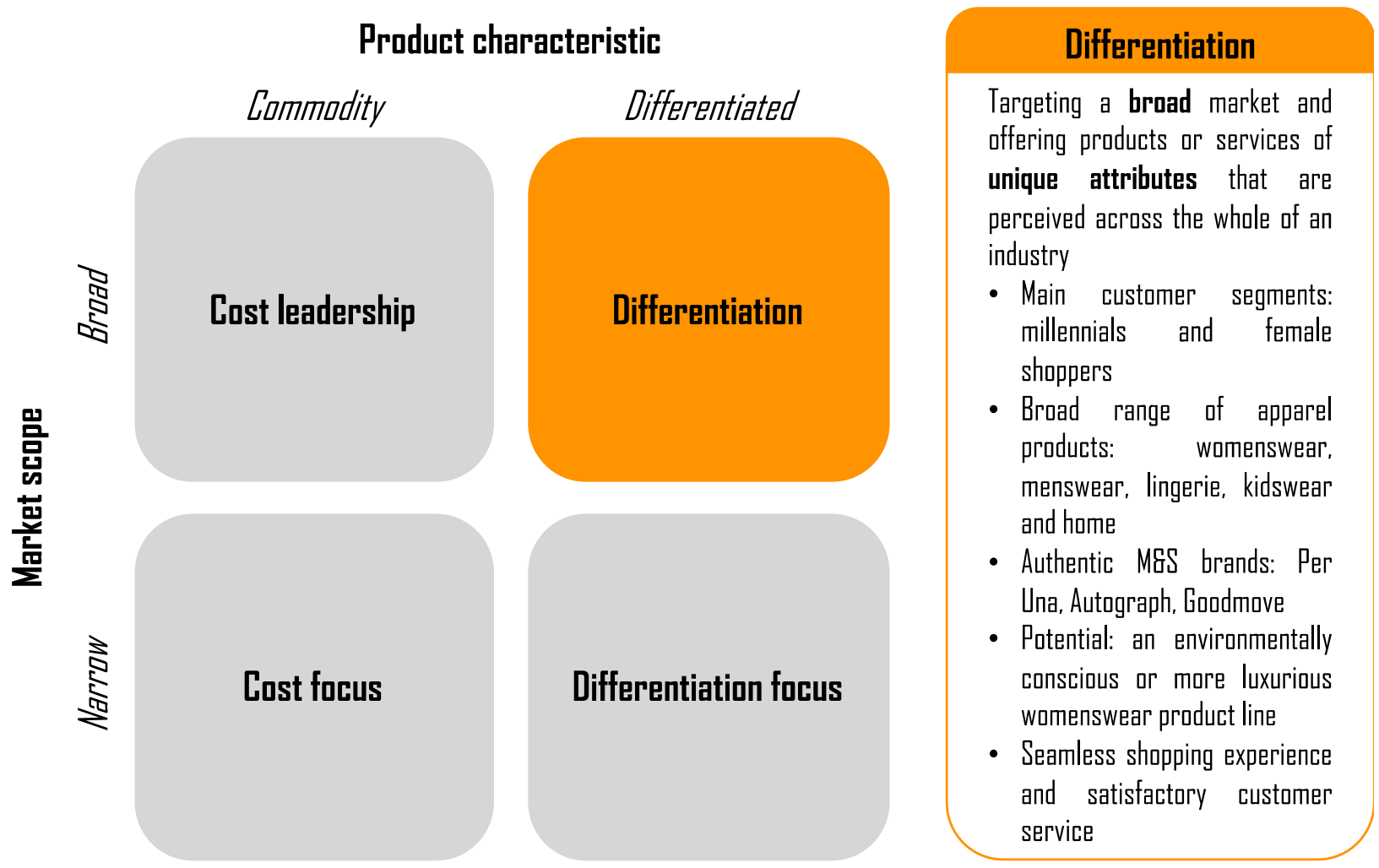

Figure 5. M\&S's market positioning strategies (adapted from Porter, 1980; McGee et al,. 2005)

Rather than being caught in the middle with an extensive yet run-of-the-mill range of products, $M \& S$ should focus on in-house brands that would enable the company to establish a signature brand image. Selective essential lines such as Per Una (stylish feminine womenswear) and Autograph (smart casualwear) need to be tailored to the typical Chinese body and must satisfy the sophisticated tastes of the millennials. Meanwhile, its technologyinfused activewear, Goodmove, should be upgraded such that it presents a key driver. It is also recommended that $M \& S$ develops a new environmentally conscious product line or a more luxurious womenswear sub-brand in order to distinguish itself from the other mid-range players and to enhance its value in the customers' eyes. In terms of pricing, there should be a balance between superior quality and reasonability, that is, the pricing should not be so low 
that it indicates cost leadership but not so high that it excludes a number of customer segments.

Meanwhile, innovation is an element that must not be overlooked in the differentiation strategy (Semuel et al., 2017). Here, M\&S should seek innovative solutions to improve product quality and to enhance its service from the first stage to the aftersales stage. In addition, to ensure a satisfactory customer experience, ensuring the company has a strong ecommerce and digital presence is crucial.

\subsection{Supply Network}

Out of the four entry modes proposed by Huang and Sternquist (2007) and shown in Figure 6 below, a franchise strategy involving a low level of commitment is recommended, which will prevent the failures that were due to M\&S's adoption of a wholly owned strategy in China (Independent, 2007). This will help to minimise the risks of initial investment costs, huge operating expenditure and a complicated management process. In fact, this is how $M \& S$ currently operates in both Hong Kong and Macau (M\&S ca., 2020b).

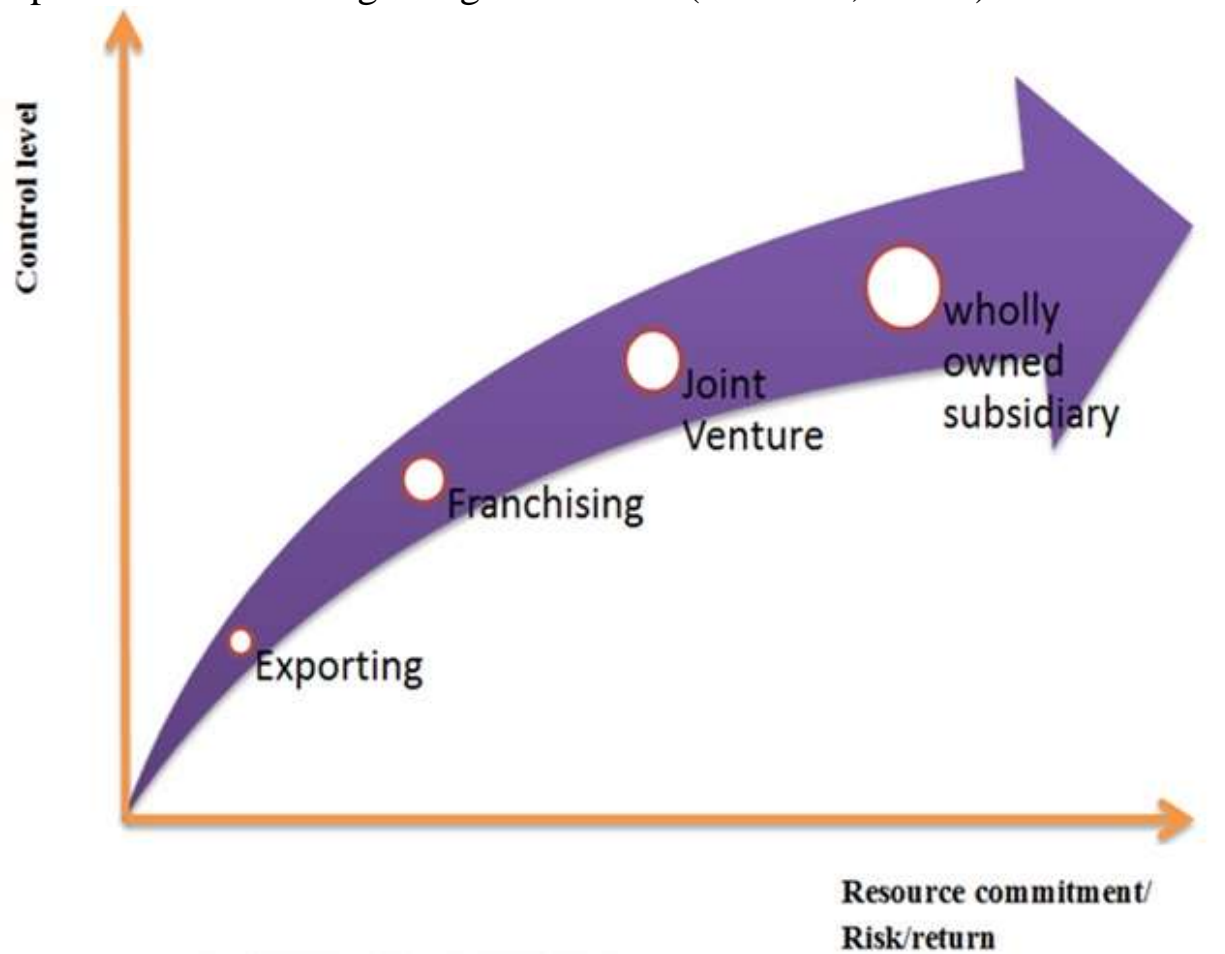

Figure 6. The hierarchy of the control level

Based on a franchise structure, exclusive activities such as research and development, design and branding should be carried out at M\&S's headquarters to ensure a brand identity is retained. Meanwhile, the franchisee's commercial expertise and exhaustive understanding of the local region means they should be responsible for the infrastructure and the distribution channel. Here, M\&S should utilise its existing Chinese suppliers and factories to optimise the overall supply network, as shown in Figure 7. 


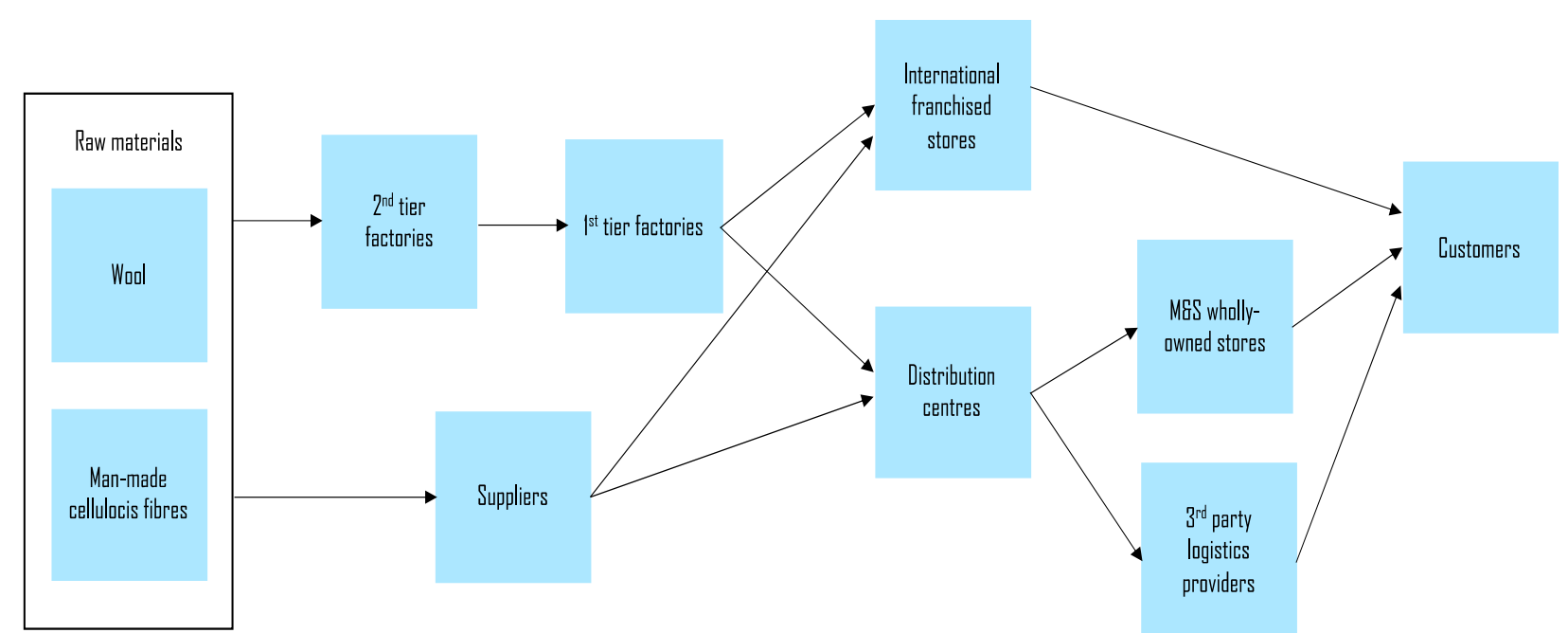

Figure 7. M\&S's supply network (adapted from Slack et al., 2013)

Meanwhile, M\&S should adapt its operations to fall in line with the evolving concept of 'new retail' in China, wherein the omnichannel, e-commerce-based strategy is key (Zheng, 2019b). This strategy includes both traditional stores and a digital presence on e-commerce and social media platforms (i.e. the website and the various web chat and mobile applications). A digitalised route-to-market model should be developed where sufficient information can flow smoothly within the distribution channel in order to simplify levels, minimise costs and obtain real-time inventory and sales data (Ding et al., 2018). And to be able to implement the effective measures to sustain the businesses in the new market, it should be another key agenda for the business to design a strategic knowledge sharing to secure continuous improvement of the quality of human resources (Tachyan et al., 2019).

A large number of Chinese millennials continue to shop at department stores, both as a mean of leisure and a means to enjoy distinctive store experiences (FBI, 2018). Thus, it is recommended that $M \& S$ starts with two franchised stores in the tier-2 and tier-3 cities in order to gain more profits from the middle-income markets, while it should ignore the overcrowded and competitive higher-level cities. Meanwhile, M\&S's technological collaborations in the fields of AI or 3D scanning should be developed to provide innovative in-store experiences. However, the online channels must receive the greatest amount of attention. Here, it would prove advantageous to open e-commerce stores on leading platforms such as Tmall, JD, and Little Red Book (Zha, 2020), while more options should be incorporated into $M \& S$ online-to-offline services. This could include multi-platform shopping, with online research carried out in terms of in-store pick up, trying before buying, in-store ordering, home delivery, and free and easy return options, as well as qualitative online reviews and feedback.

M\&S should position itself in terms of monitoring and supervising the franchisees' behaviours such that they remain in line with the overall objectives and are compliant with the franchise agreement. Efficiently managing a committed relationship with the franchisee is important to ensuring satisfactory customer experiences and enhancing brand equity throughout the entire franchise channel (Chen et al., 2018). Similarly, the downstream side related to the franchisee must be established with less unpredictability and more reliability (Kacker et al., 2016). 


\subsection{Collaboration}

In terms of vertical collaboration, $M \& S$ already has a massive network of manufacturers and suppliers in China in view of streamlining the inland product transportation. Here, it is recommended that $M \& S$ continues its franchising relationship with Al-Futtaim, which took over the M\&S stores in Hong Kong and Macau following the company's retreat (Milmo and Butler, 2018). This partner is expected to assist in the area of market entry, including in terms of market research, physical store placement and the domestic logistics for the distribution channel. Overall, as Kusumadewi (2019) emphasised, it is critical for the businesses to review and evaluate marketing and individual environment association upon the customer value, and from this process, effective communication strategy to support seamless relational activities to enhance the business performance. A holistic perspective evaluating both $\mathrm{B} 2 \mathrm{~B}$ and $\mathrm{B} 2 \mathrm{C}$ relationships should be examined to maximise the relational performance: Key topics and challenges the company has been facing should be carefully observed and evaluated by the business strategists within the organisations (Kaolawanich et al., 2020).

In terms of horizontal collaboration, $M \& S$ will continue to face numerous competitors pursuing the same customer segments. In addition to Western fast-fashion chains such as $\mathrm{H} \& \mathrm{M}$ and Zara, Uniqlo is a notable opponent given its distinctive operation that incorporates technology and sustainability focused products, as well as attractive collaborations with famous designers and targeted pricing that underlines both quality and affordability (Daxue Consulting, 2019). Concurrently, M\&S should keep an eye on the emergence of various Chinese high-street brands. These brands are adopting the idea of made-in-China labelling and are capitalising on key opinion leaders (KOLs) or influencers to attract the social medialed Chinese millennials. Examples here include Urban Revivo, often referred to as 'the Chinese Zara', and Peacebird, which is being heralded due to its merging of the Chinese and Western cultures (Rapp 2019).

M\&S should collaborate with complementary partners, specifically in terms of ecommerce and digital marketing. In addition to Tmall and JD, the two largest marketplaces in China, M\&S should be mindful of its digital presence on Little Red Book, an innovative platform that combines e-commerce and social media and is largely focused on European brands (Zha, 2020). The inclusion of electronic payment options on these e-commerce sites is crucial to aligning with Chinese consumer behaviour. Here, WeChat Pay and Alipay are the preferred methods on most platforms (Keyes and Magana, 2019).

To ensure a proficient digital marketing strategy, M\&S should cooperate with WeChat and Weibo to share its brand information and directly interact with customers, since the majority of Chinese millennials tend to assess a brand's online reputation before purchasing (FBI, 2018). The attachment to social media has also led to the rise of influencer marketing (Wu et al., 2019). In view of this, M\&S should collaborate with the fashion KOLs that are adored by Chinese millennials in order to enhance brand awareness and to entice a large number of their fans. One of the activities that is most used by KOLs involves livestreaming on social medial and e-commerce platforms to share their brand experiences (Achim, 2020). M\&S should take note of this feature and should engage in a profitable digital marketing collaboration. Figure 8 demonstrates the overview of collaborative map of M\&S in China. 


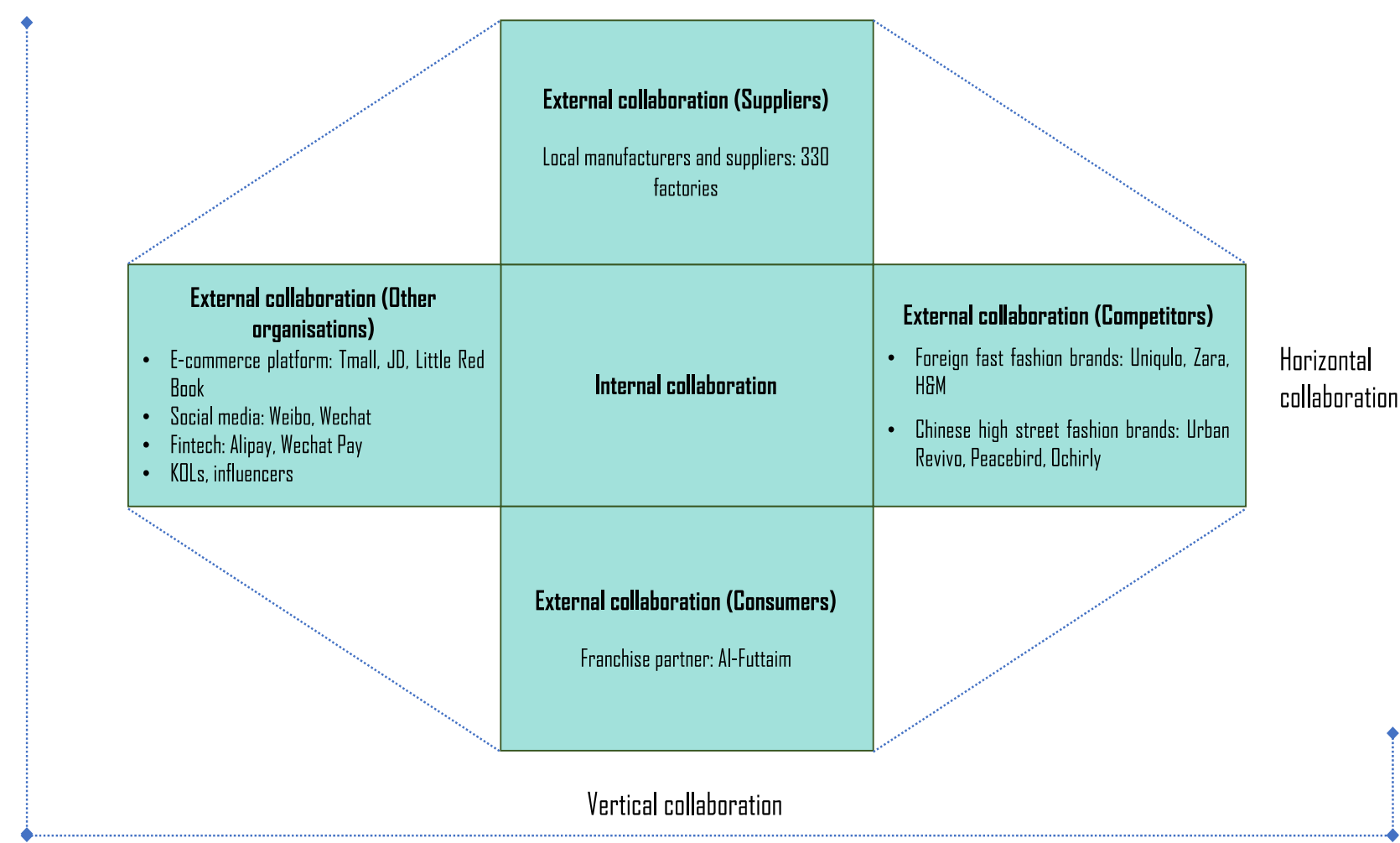

Lateral collaboration

Figure 8. M\&S's collaborative scope (adapted from Lee and Carter, 2005)

\section{Discussion}

First, various theoretical perspectives and analytical tools were applied in this discussion paper as a means of aggregating the information related to the criteria previously set out. This helped to ensure the acquisition of the attendant knowledge was more active and more systematic. The web of relational actors (De Wit, 2017) was introduced to examine the supply network of M\&S since this helped to synthesise the most prominent elements related to the firm. Rather than present a descriptive or superficial discussion, introducing the criteria of this model allowed us to obtain the most important information on M\&S in a systematic and categorised manner, which provided the foundation for the critical discussion that led to the proposal of actionable recommendations for the company.

When data is selectively assembled in terms of patterns, an improved observation of the individual factors and the attendant interrelations - which present a bigger picture - can be effectively achieved. This, in turns, lays the foundation for identifying key findings and existing issues. In the global apparel value chain depicted by Appelbaum and Gereffi (1994), the roles of various different players, such as manufacturers, suppliers, and retailers, are engaged within the same network. Here, their mutual and interactive influences are manifest, and the value-added activities, from the labour-intensive process to the contemporary strategies involving innovations and implementations to enhance effective B2B and B2C relationships, are distinguished. From this process, we could determine the critical factors in upgrading the value chain to enhance the profitable activities.

Making use of a framework that has been assessed by previous studies and authors helps to reduce the time and effort required to research and create new material and adds various new experiences and implications for the relevant fields of study, contributing to the 
attendant theories and practices. In view of proposing supply network strategies for M\&S's re-entry into China, the market entry mode was identified with reference to the hierarchy of the control levels (Huang and Sternquist, 2007). A franchise-based operation was found to be preferable due to its compatibility with the company's objective of reducing additional investment and management costs while still being able to protect its brand equity.

\section{Conclusion}

All the above notwithstanding, this paper involved a number of weaknesses, which must be acknowledged. For example, while Porter's generic strategy (McGee et al., 2005) was applied to define a specific market positioning strategy, this well-known and established theory has been criticised as being too ambiguous in terms of differentiating strategies. As argued by Datta (2010), achieving a vast market share by high pricing and uniqueness is no longer a feasible goal within the ever-changing commercial environment. In order to adapt its strategy, it was recommended that $M \& S$ focuses on the mid-end scale and on pursuing products with potential sales growth; however, distinguishing itself in terms of brand awareness, superior quality and a pricing that can reflect such characteristics is crucial.

It is always challenging for the researcher to propose recommendations within the context of real business scenarios. In fact, there exist a large number of theories that address the same topic, and, in order to avoid confusion, it is crucial to identify the differences and to employ the most relevant approach. Generally speaking, an analytical tool consists of abundant information that may lead to an overabundance of information and thus can present an obstruction to critical analysis. Thus, it is important to extract appropriate details in order to achieve the set objectives. There were two main goals involved in examining M\&S's supply network, one related to its current organisational performance and one related to its future strategy. While the model of relational actors (De Wit, 2017) was used to ensure a comprehensive review, the supply chain map (Slack et al., 2013) was chosen to clarify in detail how $M \& S$ should formulate its plan based on actionable relationships with the stakeholders, while, in order to analyse China's apparel industry and market, Porter's (1990) diamond model was selected. The power of this form of diagrammatic information lies in revealing the national characteristics and competitive advantages. Nevertheless, in order to be able to enter a specific market, the company should place a specific emphasis on market structure, rivalry, and the demand conditions.

Overall, this paper presents a pilot exploration undertaken on a conceptual level. To validate and develop more actionable implications in response to the real market environment, a detailed focus on more mid- to long-term business strategies is required. Moreover, both market and financial data and statistics should be incorporated in order to discuss future business strategies within the context of real business opportunities.

\section{References}

Achim, A. L., 2019. Gen Zers vs. Millennials: How and why brands must know the difference [online]. Jing Daily. Available from: https://jingdaily.com/gen-zers-vsmillennials-how-and-why-brands-must-know-the-difference/ [Accessed 27 May 2020].

Achim, A. L., 2020. Trends in digital marketing in China [online]. Jing Daily. Available from: https://jingdaily.com/trends-in-digital-marketing-in-china/ [Accessed 27 May 2020]. 
Appelbaum, R. P. and Gereffi, G., 1994. Power and profits in the apparel commodity chain. In: Bonacich, E., Cheng, L. and Chinchilla, N., eds. Global Production: The Apparel Industry in the Pacific Rim. Philadelphia: Temple University Press, 42-64.

Bell, D. R., Gallino, S. and Moreno, A., 2018. Offline showrooms in omni-channel retail: Demand and operational benefits. Management Science, 64 (4), 1629-1651.

Bhardwaj, V. and Fairhurst, A., 2010. Fast fashion: Response to changes in the fashion industry. The International Review of Retail, Distribution and Consumer Research, 20 (1), 165-173.

Birtwhistle, T., 2017. eCommerce in China - the future is already here [online]. PwC China. Available from: https:/www.pwccn.com/en/retail-and-consumer/publications/totalretail-2017-china/total-retail-survey-2017-china-cut.pdf [Accessed 27 May 2020].

Briggs, F., 2019. M\&S selects Global-e to support international online sales growth [online]. Retail Times. Available from: https://www.retailtimes.co.uk/ms-selects-global-e-tosupport-international-online-sales-growth/ [Accessed 27 May 2020].

Bu, L., Wang, J., Wang, K. W. and Zipser, D., 2019. China digital consumer trends 2019: Discovering the next wave of growth [online]. McKinsey Digital. Available from: https://www.mckinsey.com/ /media/mckinsey/featured\%20insights/china/china\%20dig ital\%20consumer\%20trends\%20in\%202019/china-digital-consumer-trends-in2019.ashx [Accessed 27 May 2020].

Butler, S., 2018. Is fast fashion giving way to the sustainable wardrobe? [online]. Available from: https://www.theguardian.com/business/2018/dec/29/fast-fashion-giving-waysustainable-wardrobe [Accessed 27 May 2020].

Chen, Y., Chung, S. H. and Guo, S., 2018. Franchising contracts in fashion supply chain operations: models, practices, and real case study. Annals of Operations Research, (August 2018), 1-46.

Cheng, P., Fu, Y. and Lai, K. K., 2018. Supply Chain Risk Management in the Apparel Industry. Abingdon: Routledge.

Datta, Y., 2010. A critique of Porter's cost leadership and differentiation strategies. Chinese Business Review, 9 (4), 37-51.

Daxue Consulting, 2019. The fast fashion industry in China dresses the new mix \& match [online]. Daxue Consulting. Available from: https://daxueconsulting.com/fast-fashionindustry-china/ [Accessed 27 May 2020].

De Wit, B., 2017. Strategy synthesis: For leaders. 5th edition. Andover: Cengage Learning EMEA.

Ding, J., Lannes, B., Zhu, L., Gao, H., Peng, L., Song, F. and Jiang, Z., 2018. Embracing China's New Retail [online]. Bain \& Company. Available from: https://www.bain.com/insights/embracing-chinas-new-retail/ [Accessed 27 May 2020].I

FBI, 2018. Understanding Chinese millennial's apparel shopping behavior and attitudes Survey findings [online]. Fung Business Intelligence. Available from: https://www.fbicgroup.com/sites/default/files/ChineseMillennial_2018.pdf [Accessed 27 May 2020].

FBI, 2019. China apparel market update 2019 Part 1: Market overview and competitive landscape analysis [online]. Fung Business Intelligence. Available from: https://www.fbicgroup.com/sites/default/files/Apparel_Industry_Series_2019_Part1.pdf [Accessed 27 May 2020].

$\mathrm{Fu}, \mathrm{T} ., 2015$. Impact of labor cost changes on the competitiveness of China's textile industry. International Journal of Economics, Commerce and Management, 3 (2), 1-8.

Gereffi, G. and Frederick, S., 2010. The global apparel value chain, trade, and the crisis: Challenges and opportunities for developing countries. In: Cattaneo, O., Gereffi, G. and 
Startitz, C., eds. Global value chains in a postcrisis world: A development perspective. Washington: World Bank.

Guan, Z., Xu, Y., Jiang, H., and Jiang, G., 2019. International competitiveness of Chinese textile and clothing industry - a diamond model approach. Journal of Chinese Economic and Foreign Trade Studies, 12 (1), 2-19.

Hooker, L. and Espiner, T., 2018. How can M\&S get back in fashion? [online]. BBC. Available from: https://www.bbc.co.uk/news/business-44209490 [Accessed 27 May 2020].

Huang, Y. and Sternquist, B., 2007. Retailers' foreign market entry decisions: An institutional perspective. International Business Review, 16, 613-629.

Independent, 2007. M\&S to open store in China [online]. Independent. Available from: https://www.independent.co.uk/news/business/news/mamps-to-open-store-in-china399198.html [Accessed 27 May 2020].

Ingenico, 2019. M\&S chooses Ingenico Enterprise Retail to deliver a true omnichannel payment experience for its customers in the UK [online]. Ingenico. Available from: https://www.ingenico.co.uk/company/press-releases/group/pressreleases/all/2019/09/ms-chooses-ingenico-enterprise-retail-to-deliver-a-trueomnichannel-payment-experience-for-its-customers.html [Accessed 27 May 2020].

Jung, H. Y., Choi, Y. J. and Oh, K. W., 2020. Influencing factors of Chinese consumers' purchase intention to sustainable apparel products: Exploring consumer "attitudebehavioral intention" gap. Sustainability, 12, 1770-1783.

Kaolawanich, R., Oe, H., Yamaoka, Y., \& Chang, C. Y., 2020. A Discussion of a Luxury Apparel Brand Strategy in an Emerging Market: Conceptual Model with Network Perspectives. SIASAT, 4(2), 58-72.

Kacker, M., Dant, R. P., Emerson, J. and Coughlan, A. T., 2016. How firm strategies impact size of partner-based retail networks: Evidence from franchising. Journal of Small Business Management, 54 (2), 506-531.

Keyes, D. and Magana, G., 2019. Report: Chinese fintechs like Ant Financial's Alipay and Tencent's WeChat are rapidly growing their financial services ecosystems [online]. Business Insider. Available from: https://www.businessinsider.com/china-fintechalipay-wechat?r=US\&IR=T [Accessed 27 May 2020].

Kusumadewi, R., 2019. The Role of Marketing and Individual Environment Association in Elevating the Customer Value. Budapest International Research and Critics Institute (BIRCI-Journal), 451-460.

Lee, K. and Carter, S., 2005. Global Marketing Management. Oxford University Press.

Li, F., Frederick, S. and Gereffi, G., 2019. E-commerce and industrial upgrading in the Chinese apparel value chain. Journal of Contemporary Asia, 49 (1), 24-53.

Liu, Y. and Yang, S., 2019. Spotlight: China remains reliable supplier of global fashion brands amid trade tensions with U.S. [online]. Xinhua. Available from: http://www.xinhuanet.com/english/2019-08/08/c_138293338.htm [Accessed 27 May 2020].

Macchion, L., Moretto, A., Caniato, F., Caridi, M., Danese, P. and Vinelli, A., 2015. Production and supply network strategies within the fashion industry. International Journal of Production Economics, 163, 173-188.

Maguire, L., 2019. In 2019, fast fashion companies grew up [online]. Vogue Business. Available from: https://www.voguebusiness.com/consumers/2019-fast-fashionmissguided-boohoo-asos-prettylittlething-nastygal-revolve [Accessed 27 May 2020].

McGee, J., Thomas, H. and Wilson, D., 2005. Strategy: Analysis and Practice. 1st edition. Maidenhead: McGraw-Hill. 
Milmo, D. and Butler, S., 2018. Marks \& Spencer sells Hong Kong stores as it retreats from overseas markets [online]. The Guardian. Available from: https://www.theguardian.com/business/2018/jan/02/marks-spencer-sells-hong-kongmacau-al-futtaim [Accessed 27 May 2020].

M\&S, 2018. M\&S Clothing and Home logistics changes: Hardwick distribution centre to close - DHL appointed to run new South East distribution centre [online]. Marks and Spencer. Available from: https://corporate.marksandspencer.com/media/pressreleases/2018/m-and-s-clothing-and-home-logistics-changes [Accessed 27 May 2020].

M\&S, 2019a. M\&S Annual Report \& Financial Statements 2019 [online]. Marks and Spencer. Available from: https://corporate.marksandspencer.com/documents/msar2019/full-annual-report.pdf [Accessed 27 May 2020].

M\&S, 2019b. M\&S partners with six start-ups in first year of founders factory retail joint venture [online]. Marks and Spencer. Available from: https://corporate.marksandspencer.com/media/press-

releases/5c2f8d617880b21084450f5e/m-and-s-partners-with-six-start-ups-in-first-yearof-founders-factory-retail-joint-venture [Accessed 27 May 2020].

M\&S, 2019c. Marks \& Spencer to introduce new way to pay with its first instalment payments option online [online]. Marks and Spencer. Available from: https://corporate.marksandspencer.com/media/pressreleases/5c2f8d617880b21084450f5e/marks-and-spencer-to-introduce-new-way-topay-with-its-first-instalment-payments-option-online [Accessed 27 May 2020].

M\&S, 2020a. Supplier management [online]. Marks and Spencer. Available from: https://corporate.marksandspencer.com/sustainability/clothing-and-home/suppliermanagement [Accessed 27 May 2020].

M\&S, 2020b. Our partners [online]. Marks and Spencer. Available from: https://corporate.marksandspencer.com/aboutus/ourpartners\#1b47ff5bd062494d8d33446a57fdad26 [Accessed 27 May 2020].

Porter, M. E., 1980. Competitive strategy: Techniques for analyzing industries and competitors. New York: Free Press.

Porter, M. E., 1990. The competitive advantage of nations. Harvard Business Review, 68 (2), 73-93.

Rapp, J., 2018. Why Western fashion brands fail in China, and tips on succeeding in a country where millennial consumers are taking over [online]. South China Morning Post. Available from: https://www.scmp.com/lifestyle/fashionbeauty/article/2138570/why-western-fashion-brands-fail-china-and-tips-succeeding [Accessed 27 May 2020].

Rapp, J., 2019. Five Chinese high street fashion brands to watch as they go global, and displace the likes of Zara, H\&M in China [online]. South China Morning Post. Available from: https://www.scmp.com/lifestyle/fashion-beauty/article/3018369/fivechinese-high-street-fashion-brands-watch-they-go [Accessed 27 May 2020].

Ritson, M., 2017. Mark Ritson: This is not just a decline, this is an M\&S decline [online]. Marketing Week. Available from: https://www.marketingweek.com/mark-ritson-msdecline/ [Accessed 27 May 2020].

Rizzo, E., 2019. The evolution of omnichannel retail [online]. Forbes. Available from: https://www.forbes.com/sites/forbestechcouncil/2019/10/04/the-evolution-ofomnichannel-retail/\#4f8a2568903a [Accessed 27 May 2020].

Romdonny, J. and Maskarto Lucky Nara Rosmadi, 2019. Factors affecting customer loyalty in products. Budapest International Research and Critics Institute (BIRCI-Journal): Humanities and Social Sciences, 2(1). 337-343. 
Rooney, S., 2019. What do Chinese Consumers want from Western brands? [online]. EntSight. Available from: https://entsight.com/blog/what-do-chinese-consumers-wantfrom-western-brands [Accessed 27 May 2020].

Santamaria, B., 2018. M\&S links with Microsoft to test AI tech in stores [online]. Fashion Network. Available from: https://uk.fashionnetwork.com/news/m-s-links-withmicrosoft-to-test-ai-tech-in-stores,990251.html [Accessed 27 May 2020].

Semuel, H., Siagian, H. and Octavia, S., 2017. The effect of leadership and innovation on differentiation strategy and company performance. Procedia - Social and Behavioral Sciences, 237, 1152-1159.

Slack, N., Brandon-Jones, A. and Johnston, R., 2013. Operations Management. 7th edition. Harlow: Pearson.

Stein, S., 2019. How could changing consumer trends affect fast-fashion leaders H\&M and Zara? [online]. Forbes. Available from: https://www.forbes.com/sites/sanfordstein/2019/02/10/how-could-changing-consumertrends-affect-fast-fashion-leaders-hm-and-zara/\#5230f3a36f48 [Accessed 27 May 2020].

Tachyan, Z., Rosmadi, M. L. N., \& Ulfha, S. M. (2019). The Role of Knowledge Sharing to Improve the Quality of Human Resources. Budapest International Research and Critics Institute (BIRCI-Journal): Humanities and Social Sciences, 2(1), 186-192.

Vincent, M., 2018. M\&S is finally coming to the online retail party - like it's 1999 [online]. Financial Times. Available from: https://www.ft.com/content/ea497d0e-5e7a-11e89334-2218e7146b04 [Accessed 27 May 2020].

Wood, Z., 2016. M\&S to close 30 UK stores and cut back on clothing [online]. The Guardian. Available from: https://www.theguardian.com/business/2016/nov/08/m-ands-marks-spencer-close-80-stores-major-overhaul [Accessed 27 May 2020].

Wood, Z. and Butler, S., 2018a. Seven reasons why Marks \& Spencer is in trouble [online]. The Guardian. Available from: https://www.theguardian.com/business/2018/may/23/seven-reasons-why-marksspencer-is-in-trouble [Accessed 27 May 2020].

Wood, Z. and Butler, S., 2018b. Marks \& Spencer to close 100-plus stores by 2022 in 'radical' plan [online]. The Guardian. Available from: https://www.theguardian.com/business/2018/may/22/marks-spencer-close-stores [Accessed 27 May 2020].

Wood, Z., 2019a. Cheaper rivals and online retailers have usurped M\&S's faded glory [online]. The Guardian. Available from: https://www.theguardian.com/business/2019/sep/07/marks-and-spencer-high-streetcrisis-fashion-retail-food [Accessed 27 May 2020].

Wood, Z., 2019b. Marks \& Spencer to offer 'buy now, pay later' option online [online]. The Guardian. Available from: https://www.theguardian.com/business/2019/oct/01/marksspencer-to-offer-buy-now-pay- later-option-online [Accessed 27 May 2020].

Wood, Z. and Butler, S., 2019. 'Jeansgate' exposes Marks and Spencer's deeper fashion flaw [online]. The Guardian. Available from: https://www.theguardian.com/business/2019/jul/13/jeansgate-exposes-marks-andspencers-deeper-fashion-flaw [Accessed 27 May 2020].

Wood, Z., 2020a. Marks \& Spencer depot closures put nearly 700 jobs at risk [online]. The Guardian. Available from: https://www.theguardian.com/business/2020/feb/13/marksspencer-depot-distribution-centres-closures-nearly-700-jobs-risk [Accessed 27 May 2020]. 
Wood, Z., 2020b. Boohoo worth more than M\&S after Christmas sales surge [online]. The Guardian. Available from: https://www.theguardian.com/business/2020/jan/14/boohoomarks-spencer-christmas-sales [Accessed 27 May 2020].

WTO, 2019. World trade statistical review 2019 [online]. World Trade Organisation. Available from: https://www.wto.org/english/res_e/statis_e/wts2019_e/wts2019_e.pdf [Accessed 27 May 2020].

Wu, W., 2019. Fast fashion must be high-end to compete in China [online]. Jing Daily. Available from: https://jingdaily.com/fast-fashion-china-other-stories-cos-topshoptmall/ [Accessed 27 May 2020].

Wu, W., Chen, Z. and Zheng, R., 2019. What brands should have learned about China in 2019 [online]. Jing Daily. Available from: https://jingdaily.com/what-brands-shouldhave-learned-about-china-in-2019/ [Accessed 27 May 2020].

Xie, J., 2019. Foreign fast fashion brands face falling sales in China [online]. Global Times. Available from: https://www.globaltimes.cn/content/1149687.shtml [Accessed 27 May 2020].

Zha, W., 2020. E-commerce in China: The rules of the game for starters [online]. FashionUnited. Available from: https://fashionunited.uk/news/retail/e-commerce-inchina-the-rules-of-the-game-for-starters/2020033148237 [Accessed 27 May 2020].

Zhang, M., Kong, X. X., and Ramu, S. C., 2015. The transformation of the clothing industry in China. Asia Pacific Business Review, 22 (1), 86-109.

Zheng, R., 2017. What drives the heavy consumption of Chinese millennials? [online]. Jing Daily. Available from: https://jingdaily.com/chinese-millennial-big-spenders/ [Accessed 27 May 2020].

Zheng, R., 2019a. One question, three answers: Are Chinese millennials willing to pay more for sustainable goods? [online]. Jing Daily. Available from: https://jingdaily.com/chinese-millennials-sustainable/ [Accessed 27 May 2020].

Zheng, R., 2019b. 3 unique features of China's New Retail [online]. Jing Daily. Available from: https://jingdaily.com/3-unique-features-of-chinas-new-retail/ [Accessed 27 May 2020]. 